\title{
Impact of Hairdin, Miro Khan and Shahdad Kot Drainage on Hamal Dhand, Sindh
}

\author{
A. A. Mahessar \\ Sindh Barrages Improvement Project \\ Irrigation Department, \\ Government of Sindh \\ Sindh, Pakistan \\ amahessar@yahoo.com
}

\author{
S. Qureshi \\ Dr. M. A. Kazi \\ Institute of Chemistry, \\ University of Sindh, \\ Jamshoro, Pakistan \\ s.dr582@gmail.com
}

\author{
A. L. Qureshi \\ U.S.-Pakistan Centers for Advanced \\ Studies in Water, Mehran University of \\ Engineering and Technology, \\ Jamshoro, Pakistan \\ alqureshi.uspcasw@faulty.muet.edu.pk
}

\author{
S. F. Shah \\ Department of Environmental \\ Engineering, Mehran University of \\ Engineering and Technology, \\ Jamshoro, Pakistan \\ syedafarwashah1@gmail.com
}

\author{
A. N. Laghari \\ Department of Energy and \\ Environment, Quaid-e-Awam University \\ of Engineering, Science and Technology, \\ Nawabshah, Pakistan \\ mashaalnasirlaghari@gmail.com \\ F. A. Shaikh \\ Department of Chemical Engineering, \\ Quaid-e-Awam University of \\ Engineering, Science and Technology, \\ Nawabshah, Pakistan \\ faheemakhtar86@yahoo.com
}

\begin{abstract}
Safe drinking water is a basic need. Surface water bodies are the primary source of safe water. Drain water, industries, urban/rural effluents, and waste materials are often disposed into surface water bodies without any treatment. All major water bodies of Sindh province are thus more or less polluted. These water bodies are interconnected with the Indus River like the artery system for blood circulation in bodies of living things. The main source of contamination of Hamal Lake is the disposal of the effluents of Hairdin drain, Miro Khan drain, and Shahdad Kot drain. This lake's main source of fresh water is rained from Khirthar mountains. Hamal lake is connected through the Main Nara Valley drain (MNVD) to Manchar lake that eventually outfalls into Indus River. Hence, drain water pollutes not only Hamal and Manchar lakes but also Indus River due to their interconnection. Presently, right bank outfall drains (RBOD I-III) have been constructed for safe disposal of drain effluents thus avoiding the polluting of freshwater bodies.
\end{abstract}

Keywords-Hamal lake; agricultural and industrial effluents; drainage system; RBOD

\section{INTRODUCTION}

Wetlands areas contain unique land cover classes. They are some of the most diverse ecosystems in the world [1]. Such areas, where moisture is produced due to saturation, comprise of distinctive land cover classes. Many factors exert an influence on wetland stability or degradation. Land use and land cover change influence wetlands in most regions [2-5]. The environment impact of drainage has reached a critical crossroads and requir extensive research. In the past, drainage systems have been designed for continuous operation, and very little consideration was given to the environmental impact of the drainage water on surface water quality. Continuous operation of drainage systems in arid areas results in over drainage of irrigated fields with the resultant loss of water and an excessive load of salt being transported to surface water along with any dissolved agricultural chemicals [6-7]. The problem with salt accumulation in the wetlands/reservoirs highlights the environmental concerns associated with drainage from arid irrigated lands [8].

Not only salinity, but also toxic elements found in the drainage water are issues of concern. There are major concerns regarding pollution and the discharge of phosphorus and pesticides in drainage water. In response to the environmental impacts of drainage water, research is being conducted on managing drainage water discharges to reduce the total load of pollution in the drainage water and the salinity in drainage water. Human activities are polluting freshwater bodies. Globally, about 1.5 billion people have no safe drinking water access and about 5 million deaths per year are attributed to waterborne diseases [9]. The untreated effluents of factories from LBOD catchment area contain high amounts of dangerous $\mathrm{pH}, \mathrm{EC}, \mathrm{TDS}$, TSS, BOD5, COD, making them unfit and must not be discharged into irrigation and drainage systems [10]. The main sources of fresh water can be affected by the discharge of untreated wastewater and dumping of effluents which have an adverse impact on freshwater bodies [11]. Safe drinking water is a basic and global human need [12]. The major cause of contamination was found to be the susceptibility of drinking water sources to intrusions from the nearest contamination sources [13].

Many changes in physico-chemical parameters of water and biota were brought about by human activities which have significant impact on ecological conditions and fauna and flora. Lakes are one of the most productive ecosystems 
and the qualitative and quantitative study of species present in lakes is essential, especially for the development and improvement of natural resources [14]. It is shown by the physic chemical parameter tests that the algal flora of Main Nara Valley Drain (MNVD) made its way in to the Manchar Lake, District Dadu, Sindh. Metals identified are mostly toxic such as $\mathrm{Al}, \mathrm{Cu}, \mathrm{Mn}, \mathrm{Pb}, \mathrm{Zn}, \mathrm{Co}$ and $\mathrm{Fe}$. These metals are different from other toxic materials due to nondegradable nature in the environment. The physico-chemical properties like alkalinity, temp, DO, conductivity, TDS, turbidity, $\mathrm{pH}$ and hardness of Kinjhar Lake were investigated in $[15-16]$.

Hamal lake is located in the west of Warrah town, in the Shahdad Kot District at $27^{\circ} 23^{\prime} \mathrm{N}$, and $67^{\circ} 55^{\prime} \mathrm{E}$. The covered area of the lake is about $25 \mathrm{~km}$ in length and $10 \mathrm{~km}$ in width. Hamal lake comprised initially of three water bodies, namely Sarroh, Badram, and Kachhari. On the western side of the lake, there is a hilly region of Kachho called Khirthar Hills (jabal), which starts from Karachi South and ends at Balochistan North. On the eastern side, flood protective (FP) bund was constructed during the British period for the protection of fertile lands and populated areas from hill torrent waters. This FP bund was constructed parallel to Hamal lake along the hills. During the flood season the excess of water drains through Hamal regulator into MNVD and finally falls into Manchar lake. Hamal is a shallow lake with a maximum water depth of 5-11 feet which was initially free from contamination and pollution (Figure 1). But due to water mismanagement, the lake got polluted, and the poor quality of lake water is threatening its ecosystem.

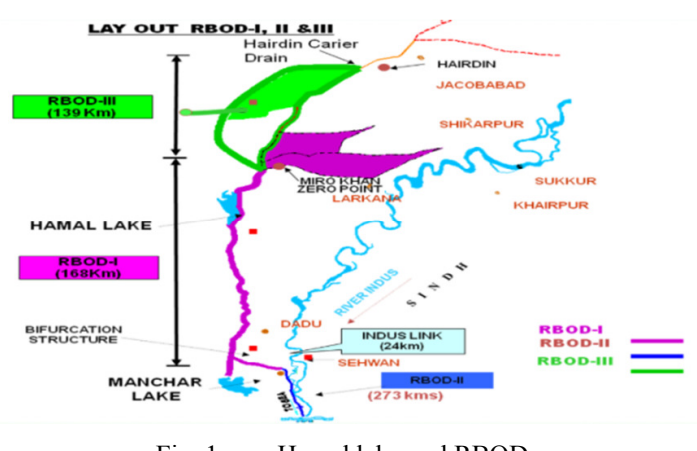

Fig. 1. Hamal lake and RBOD

\section{MATERIALS AND METHODS}

Water samples of Hamal lake were collected from 7 locations. Two locations were selected at Shadadkot, and Miro Khan Drains outfall into Hamal Lake (Figure 2). These samples were collected in polyethylene bottles and sent to the Water Analyzing Laboratory of Pakistan Council of Research in Water Resources (PCRWR). All samples were collected from the following locations.

- Sample 1: Outfall of Miro Khan drain at zero point.

- Sample 2: Outfall of Shahdad Kot drain at zero point.

- Sample 3: Mixing points of drains in Hamal drain.

- Sample 4: Sarroh lake, outfall water of Hairdin drain.
- Sample 5: Badram lake, near the fishermen's village.

- Sample 6: Upstream of Regulator MNVD.

- Sample 7: Downstream of the Regulator of MNVD.

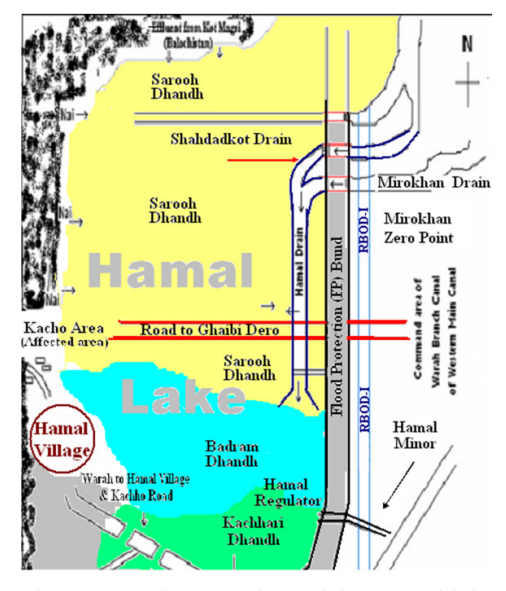

Fig. 2. Diagram view of the Hamal lake

\section{RESULTS AND DISCUSSION}

Figure 3 shows the $\mathrm{pH}$ values of the samples of the lake along with the lower and upper NEQS (National Environmental Quality Standards) limits. The $\mathrm{pH}$ values of samples 1-3 are below the lower limit. Low $\mathrm{pH}$ values may harm the fauna of the lake. Figure 4 exhibits the samples' electrical conductivity (EC). This Figure shows that the water is highly saline (see also Figure 6), which is not suitable for drinking or for the local fish.

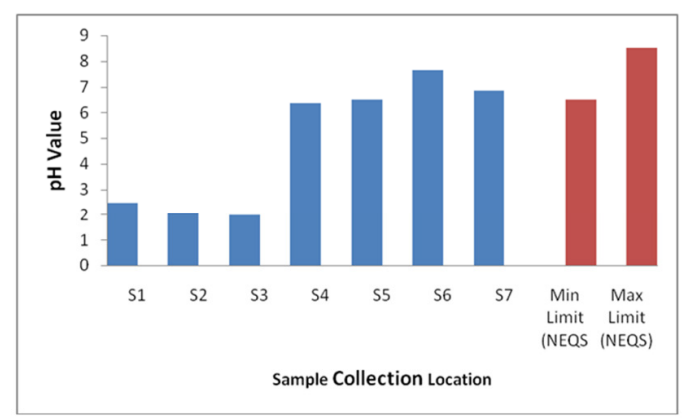

Fig. 3. $\mathrm{pH}$ values of samples collected from the lake

Total dissolved salts (TDS), chlorides, hardness and sulfates are shown in Figure 5. Chloride values are much higher than those allowable under NEQS. The hardness of all samples is higher than the NEQS limits. Sulphate values were $1071.4,2073.8,1457.2$ and $2607 \mathrm{mg} / 1$ in locations 1,2 , 4 and 5 respectively as shown in Figure 5 . The results of copper $(\mathrm{Cu})$ samples indicate that the value of $\mathrm{Cu}$ is within the permittable limits except for the sample of location 3 (Figure 7). Results show that the values of the different parameters of the effluents are much higher than those allowablefrom NEQS. People along Shahdad Kot drain and Miro Khan drain use drain effluents due to freshwater 
unavailability. The consumption of this polluted water causes negative impacts.

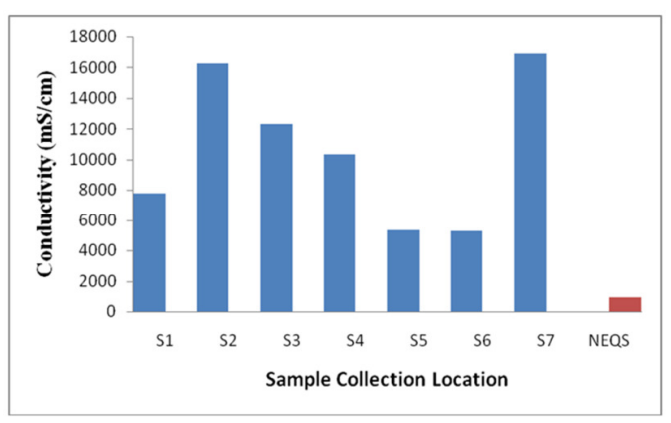

Fig. 4. EC of samples

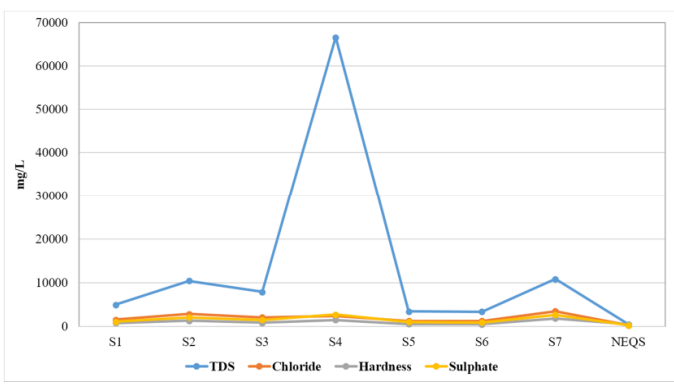

Fig. 5. Values of TDS, chloride, hardness and sulphate

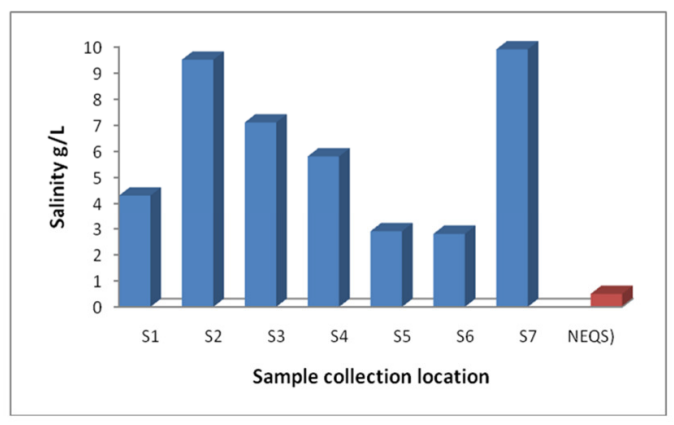

Fig. 6. Salinity of samples

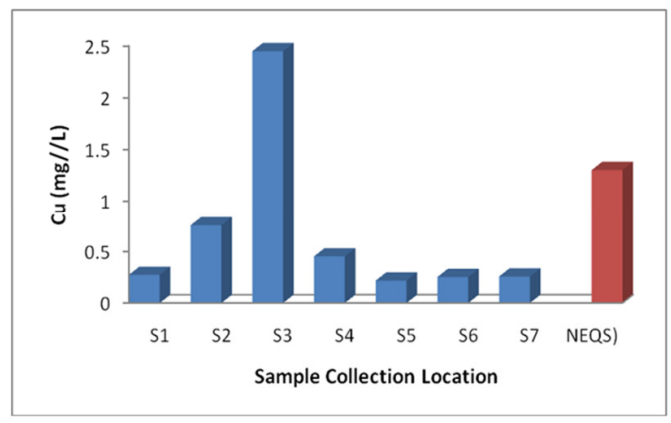

Fig. 7. $\quad \mathrm{Cu}$ of samples

\section{A. Adverse Impact on the Ecosystem of the Lake}

\section{1) Poor Drinking Water Quality}

In the lake vicinity there are many villages situated in its banks and islands. Groundwater was highly saline on both eastern and western banks of the lake. Therefore, the locals have no option of drinking water besides the contaminated surface drain water. During the drought season, the locals were in dire need of drinking water. Hand pumps have been installed at a depth of 15 to 20 feet at some locations. The villagers bring freshwater from hand pumps from 15 to $20 \mathrm{~km}$ distance and when they can't, they use drainage water.

\section{2) Adverse Impact on Health}

Adverse environmental conditions have risen in the area. Endemic water-borne diseases have been spread out in the Hamal lake area, diseases including hepatitis-A, B and C, diarrhea, tuberculosis, gastroenteritis, malaria, asthma, respiratory diseases, and typhoid fever.

\section{3) Negative Impact on Soil}

Local people cultivate wheat and oilseeds through pumping contaminated water from the lake located in the adjacent area while the people of Kachho cultivate crops on rainfall water. Cultivation on saline/contaminated water is severely affecting soil conditions, and it is feared that this practice would ultimately make soil unproductive for any crop.

\section{4) Degradation of Fertile Land}

The adjacent area and covered lands of the lake were fertile. These lands used to produce high yields of crops like wheat and oilseed. In the flood of 1976, the area of the lake was filled with water, and at the same time, the drainage effluents of various districts of Sindh Province and Balochistan were diverted into the lake. The drainage water was highly saline, which contaminated the lake water. The effluent water maintained its level about 8 to 10 feet above fertile lands in the left (eastern) bank of the lake. Therefore, seepage water has raised the water-table depth. This caused waterlogging and salinity which led to the deterioration of fertile lands. The problem spread out in an area of about 7$8 \mathrm{~km}$ in width, and $25-30 \mathrm{~km}$ in length. Thus, thousands of acres of first-class lands fell victims to waterlogging and salinity.

\section{5) Impact on Fishing}

There were many fishermen villages located in the vicinity and islands of the lake. The homes of fishermen were built of reeds, bushes, and wood. Moreover, many fishermen migrated from District Badin and Indus River and the coastal areas of Sindh. In 80's the fish was caught in hundreds of tonnes, which is now reduced to only 5 or 7 tonnes per day. The leading cause of this reduction was the contaminated water released in the lake. Many local species (Paplate, Goj, Khagho, Kurriro, Theili, Shakur, Morakhi, Seengari, Jarco, Ghandan, Popri, Mundhi, Buhan, Gulfam and Dhangni ) of fish have become extinct. All lakes of Sindh province had been given on contract (under Thekedari system) to contractors including the Hamal Lake. 


\section{6) Adverse Impact on Birds}

When fresh water was available, millions of migratory and local birds used to visit in different seasons in these lands.

\section{7) Adverse Impact on the Forest}

The forest was filled with various types of trees and vegetation. The forests are mostly relics of an Indus type dense canopy together with dominant grasses such as the wild sugar canes.

\section{8) Negative Impact on Wildlife and on Livestock}

Especially this forest had been playing a pivotal pasture role for livestock and wildlife. The locals used to prosper due to the selling of timber wood and honey. Mountainous people migrated from the hilly areas for searching pasture for their sheep, goat, cow, and camel herds. Now, local and mountainous people are anxious and worried about pasture and other resources. The locals told the visiting team that the forest was home to different kinds of animals, which used to be very wild and dangerous.

\section{B. Positive Impact of Construction of RBOD I, II and III System}

RBOD projects are located on the right bank of River Indus. Construction of RBOD is an essential, prerequisite for the development of surface drainage of the right bank area, since there is no natural outfall. Completion of the RBOD project will provide drainage facilities to the existing and proposed drainage projects in Sindh, but will also provide a much desired relief to Hamal lake from the drainage units of Balochistan and Sindh. RBOD is being executed in three projects namely:

- RBOD-III, from Hairdin Pump Station (Balochistan) to Miro Khan zero point.

- RBOD-I, from MKZP up to Sehwan

- RBOD-II, from Sehwan to the Arabian Sea

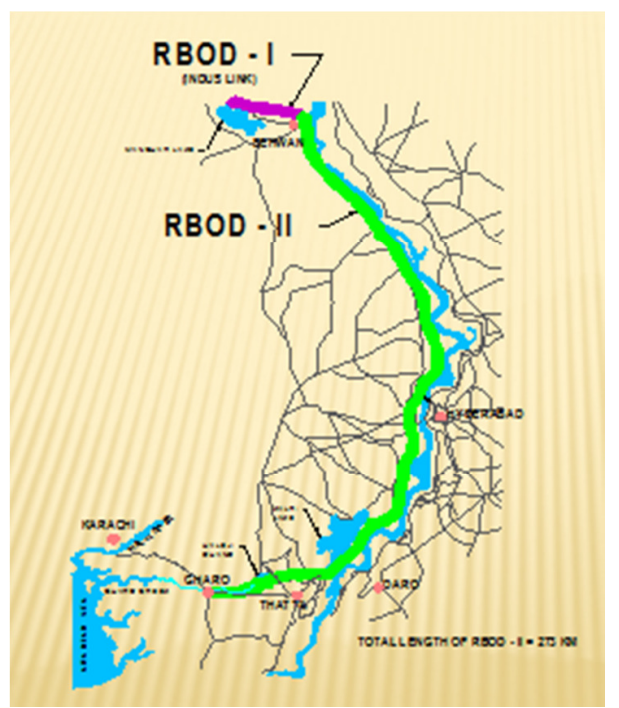

Fig. 8. RBOD-I and II
RBOD III has been constructed in Balochistan which is connected at Mirokhan drain zero point with RBOD I and RBOD I connects at cross regulator of Manchar lake with RBOD II which ultimately outfalls into the Arabian Sea through the Gharo creek. The catchment area of these drains covers some parts of Balochistan and the entire area of the right side of Indus River. Presently, there are positive and negative impacts from the construction of the RBOD system. The overall impacts of the construction of RBOD are: reduction of groundwater level, changes of hydrological conditions, land drainage resulting in changes in land use and capability. The reclamation of wetlands or highly affected saline lands results in change of these lands to croplands.

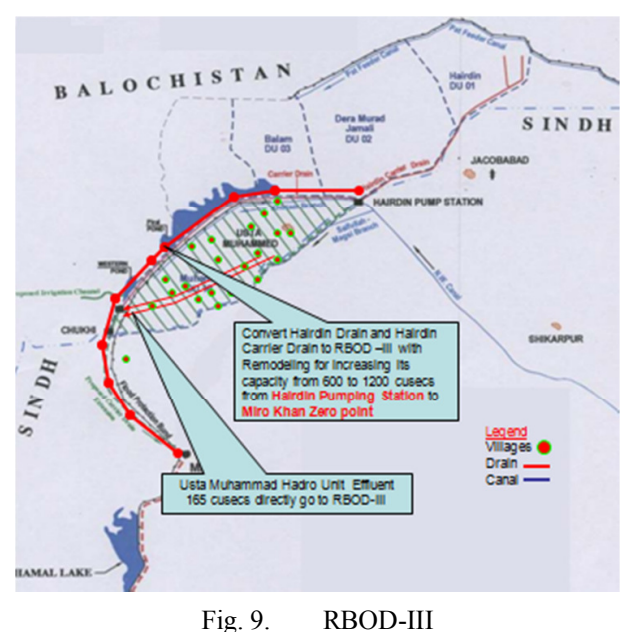

The direct impacts of the RBOD drainage system generate a series of impacts: climatic, social, economic and environmental impacts, which affect soil crops and agriculture practices. The indirect impacts, can be biological, and/or hydrological, physical, or chemical. These impacts can be positive, negative or complex. Positive impacts of the discharge are the removal of salts and other harmful substances from the soil, and the availability of drainage water for various purposes. Negative impacts of the discharge include the excessive leaching of valuable nutrients from the soil.

\section{CONCLUSIONS}

The effluents of Kot Magsi and Usta Muhammad areas are being disposed into Hamal lake from two different routes. They are found to be highly saline and polluted. They must be treated and brought to safer limits. The salinity control and reclamation projects (SCARP) tube wells installed in the catchments of Miro Khan and Shahdad Kot drains have to operate appropriately. Severe environmental and ecological issues have risen due to the unabated disposal of effluents into Hamal lake. This has resulted in the loss of monumental and historical places. Therefore, efforts for the conservation of the environment should be carried out. In this connection, environmental awareness among the locals may be created through various methods. Water quality of 
the lake and the drainage system should be appropriately monitored. The wetland management plan for the Hamal lake should be prepared and implemented. Hamal lake was historically a favorite nesting place for wildlife but is losing fast its wildlife flora and fauna. It may be declared a Ramsar site for its proper attention and treatment.

People in the area are deprived of basic facilities like pure water. Besides that, the economic conditions are too weak. Therefore, efforts should be carried out by the concerned agencies in order to provide the necessary facilities. Natural resources are being explored in the Hamal lake area. Unfortunately very little has been done for the betterment of inhabitants lives. In this regard, it must be ensured that necessary funds are being spent on the welfare of the local people. Apart from some cursory baseline studies made during the early stages, no systematic evaluation has been made on water quality, fish species and the seasonal distribution of migratory and resident birds in this coastal environment. This study, therefore, recommends the implementation of a program of physical, chemical and biological monitoring of the area. The construction of RBOD on the right side of the Indus River develops positive impacts for the reclamation of Hamal lake. Salinized and waterlogged lands will be reclaimed due to the construction of the RBOD system.

\section{REFERENCES}

[1] W. J. Mitsch, J. G. Gosselink, Wetlands, Van Nostrand Reinhold, New York, 1993

[2] Millennium Ecosystem Assessment, Ecosystems and Human WellBeing: Wetlands and Water, pp. 3-15, World Resources Institute: Washington, DC, USA, 200

[3] W. Steffen, A. Sanderson, P. D. Tyson, J. Jager, P. A. Matson, B. Moore III, F. Oldfield, K. Richardson, H. J. Schellnhuber, B. L. Turner II, R. J. Wasson, Global Change and the Earth System: A Planet under Pressure, pp. 14-18, Springer-Verlag Press, Berlin, Germany, 2004

[4] J. J. Feddema, K. W. Oleson, G. B. Bonan, L. O. Mearns, L. E. Buja, G. A. Meehl, W. M. Washington, "The importance of land-cover change in simulating future climates", Science, Vol. 310, No. 5754, pp. 1674-1678, 2005

[5] E. Lambin, X. Baulies, N. Bockstael, G. Fischer, T. Krug, R. Leemans, E. Moran, R. Rindfuss, Y. Sato, D. Skole, B. L. Turner II, C. Vogel, Land Use and Land Cover Change: Implementation Strategy, IGBP Report No.48, International Geosphere-Biosphere Programme: Stockholm, Sweden, IHDP Report No. 1, International Human Dimensions Programme on Global Environmental Change, Bonn, Germany, 1999

[6] E. J. Doering, L. C. Benz, G. A. Reichman, "Shallow-water-table concept for drainage design in semiarid and subhumid regions. Advances in Drainage", Fourth National Drainage Symposium, Vol. 13, No. 4, pp. 34-41, 1982

[7] J. E. Ayars, E. W. Christen, J. W. Hornbuckle, "Controlled drainage for improved water management in arid regions irrigated agriculture", Agricultural Water Management, Vol. 86, pp. 128-139, 2006

[8] Anonymous, A Management Plan for Agricultural Subsurface Drainage and Related Problems on the Westside San Joaquin Valley: Final Report of the San Joaquin Valley Drainage Program, California Department of Water Resources, Sacramento, California, 2015

[9] M. A. Mahar, W. A. Baloch, S. I. H. Jafri, "Diversity and seasonal occurrence of planktonic rotifers in Manchhar lake, Sindh, Pakistan", Pakistan Journal of Fisheries, Vol. 1, No. 1, pp. 25-32, 2000

[10] A. L. Korai, G. A. Sahto, K. H. Lashari, S. N. Arbani, "Biodiversity in Relation to Physicochemical Properties of Keenjhar Lake, Thatta
District, Sindh, Pakistan", Turkish Journal of Fisheries and Aquatic Science, Vol. 8, pp. 259-268, 2008

[11] K. A. Onsdorff, "What the Weitzenhoff Court got wrong?", Journal of Water Environment Law and Practice, Vol. 4, No. 1, pp. 14-18, 1996

[12] A. L. Qureshi, A. A. Mahessar, M. E. U. H. Leghari, B. K. Lashari, F. M. Mari, "Impact of Releasing Wastewater of Sugar Industries into Drainage System of LBOD, Sindh, Pakistan", International Environmental Science and Development, Vol. 6 No. 5, pp. 381-386, 2015

[13] M. A. Sohag, A. A. Mahessar, I. A. Bohio, "Pollution of Indus water and the drainage system of Sindh", The First International Conference on Environmentally Sustainable Development, Abbottabad, Pakistan, June 26-28, 2005

[14] R. Ahmad, "Studies on the chemistry control of some selected drinking and industrial waters", Pakistan Journal of Scientific and Industrial Research, Vol. 48, No. 3, pp. 174-179, 2005

[15] T. M. Jahangir, M. Y. Khuawar, S. M. Leghari, W. A. Baloach, A. A. Leghari, A. Leghari, "Some Studies on Water Quality and Biological Life at Kinjhar and Haleji Lakes of District Thatta, Sindh, Pakistan", Pakistan Journal of Biological Sciences, Vol. 3, No. 11, pp. 19651972,2000

[16] International Bank for Reconstruction and Development International Development Association, Management Report and Recommendation in Response to the Inspection Panel Investigation Report of the Pakistan National Drainage Program Project, 2006 